\title{
Agro-morphological Characterization of Maize (Zea mays L.) Hybrids Under Acid Soils in Two Contrasting Environments
}

\author{
Honoré Tekeu ${ }^{1,2}$, M. E. L. Ngonkeu ${ }^{1,3}$, Liliane N. Tandzi ${ }^{4,5}$, Appolinaire Tagne ${ }^{3} \&$ Pierre-Francois Djocgoué $^{1}$ \\ ${ }^{1}$ Department of Plant Biology, University of Yaoundé I, Yaoundé, Cameroon \\ ${ }^{2}$ Institute of Integrative Biology and Systems, Université Laval, Quebec City, QC, Canada \\ ${ }^{3}$ Department of Annual Crops, Institute of Agricultural Research for Development, Yaoundé, Cameroon \\ ${ }^{4}$ Department of Crop Production Technology, College of Technology, University of Bamenda, Bambili, \\ Cameroon \\ ${ }^{5}$ West Africa Centre for Crop Improvement, College of Agriculture and Consumer Sciences, University of \\ Ghana, Accra, Ghana
}

Correspondence: Honoré Tekeu, Institute of Integrative Biology and Systems, Université Laval, Quebec City, QC, G1V 0A6, Canada. Tel: 1-418-656-2131 Ext. 406397. E-mail: honore.tekeu.1@ulaval.ca

Received: November 29, 2020

Accepted: January 10, $2021 \quad$ Online Published: February 15, 2021

doi:10.5539/jas.v13n3p32

URL: https://doi.org/10.5539/jas.v13n3p32

The research was financed by the Gates Foundation, through the West Africa Center for Crop Improvment (WACCI) project.

\begin{abstract}
Acidic soils cover 75 to $80 \%$ of the arable soils in the humid forest areas of Cameroon, causing maize yield losses of around $69 \%$. Sixty-four accessions of maize hybrids were developped from "Line $\times$ Tester" crosses between twenty tropical inbred lines with three testers (Cam inbgp117, 88069 and 9450) and between testers themselves, and one acid tolerant open pollinated variety (ATP-SR-Y). Those inbred breeding lines were collected from CIMMYT, IITA and IRAD and the derived single hybrids were characterized using agro-morphological maize's descriptors on a completely randomized block design in two contrasting environments (Nkoemvone and Nkolbisson). The data collected was subjected to multivariate analyses. The Principal Component Analysis showed the first two components being $73.60 \%$ and $78.99 \%$ of the total variation in Nkoemvone and Nkolbisson, respectively. Furthermore, grain yield showed a positive and highly significant correlation with the plant emergence rate in Nkoemvone $(\mathrm{r}=0.61, P<0.001)$ and Nkolbisson $(\mathrm{r}=0.84, P<$ 0.001). Hierarchical Clustering Analysis indicated that these accessions forms four distinct groups, where each of the groups showed clear specific features for which the performance differs from that of the others in Nkoemvone and Nkolbisson. Characters such as plant emergence rate, prolificacy, ear appearance and grain yield have been found as important phenotypic markers for assessing agromorphological diversity of maize hybrids. These traits should necessarily be considered in maize breeding programs for varietal discrimination and formulation of cores collection of maize tolerant to aluminum and manganese toxicities in the soil.
\end{abstract}

Keywords: acidic soil, aluminum tolerance, humid forest zones, maize, manganese tolerance

\section{Introduction}

Maize is one of the most important cereal crops in the world, providing a staple food, and being used as source of income for many populations in developing countries (Tandzi et al., 2020). It is an essential source of carbohydrate for human diets and animal feed in developing countries (Undie et al., 2012). In Central Africa, it is a major staple crop and has the potential to mitigate the food insecurity in the sub region (Tandzi et al., 2015a). Corn is widely consumed in Central and West Africa (Thé et al., 2007). The way maize is processed and consumed greatly varies from one country to another, with maize flour and meal being the most popular products (USAID, 2002; Ranum et al., 2014). It is the most important food in South America, the Caribbean and Africa (Claudia, 2000; Mapiemfu, 2011). Corn bristles are used for their cholagogue, antidiuretic and antihemorrhagic properties (Lepengue et al., 2012). 
The cultivation of maize covers all of the five agro-ecological zones of Cameroon (Ngonkeu, 2009) where yields are limited by several constraints such as soil acidity (Horst, 1997), diseases and pests (Adregbola, 1994), the non-use of suitable agricultural practices as well as the unavailability and ignorance of improved seeds. Maize yields were found to be reduced significantly because of aluminum and/or manganese toxicity, with deficiencies in Ca, Mg, P, and Mo (Aldrich et al., 1975; Borrero et al., 1995; Clark, 1997; Krstic et al., 2012) inhibiting root development and reducing water absorption in plant (Mossor-Pietraszewska, 2001; Velasquez et al., 2008). The humid forest areas of the country covers 21.7 million hectares with 75 to $100 \%$ of acidic soils (Bindzi-Tsala, 1987; Ambassa-Kiki, 2002). These acidic soils hamper maize production, causing yield losses of up to $69 \%$ (Tandzi et al., 2018).

For an acceptable agricultural production, Thé et al. (2006) showed that acidic soils improvement with lime (2 $\left.t \cdot a^{-1}\right)$ increased grain yield of tolerant and susceptible maize varieties. Furthermore, Ngonkeu (2009) showed that the use of improved maize varieties coupled with the biological soil fertility processes of certain species of arbuscular mycorrhizal fungi improved the tolerance of maize plants to soil with aluminum and manganese toxicities. The given solutions are costly for resource-poor farmers (Thé et al., 2003). Wood ash at 4 t.ha $a^{-1}$ has also been used and this has significantly increased the yield in acid soils (Mbahet al., 2010). Moreever, Tandzi et al. (2015a) stated that this method is not always sustainable because of the non-availability of ash. Therefore, the use of maize cultivars tolerant to soil acidity could provide less expensive and permanent solution, contributing to sustainable crop production on acid soils (Granados et al., 1993; Welcker et al., 2005). Therefore, two hybrids (ATP-SR-Y $\times 87036$ and ATP S5 SYN-Y $\times 9450$ ) were identified as being tolerant of soil acidity (Tandzi, 2005), but these varieties are not available to farmers. Moreover, the most acid-tolerant open-pollinated (OP) variety (ATP-SR-Y) so far released since 1999, suffers yield reduction due to soil acidity within the ranges of 57 to $60 \%$ (The et al., 2006; Tekeu, 2013), becoming thereby sensitive. Among the new hybrid varieties of highly productive maize, many have interesting traits that could be exploited by breeders in breeding programs. Tandzi et al. (2015b) characterized some of the selected inbred lines under acidic soil with aluminum toxicity whereas Petmi et al. (2016) screened inbred maize lines for adaptation on acid soils in the humid forest zone of Cameroon However, no studies have been conducted to provide agro-morphological information such as emergence rate of plants, prolificacy, appearance of the ear and grain yield on the promising varieties of maize hybrids developed by Tekeu et al. (2015). This study was investigate to characterize the agro-morphological performances of maize hybrids varieties under acidic soils conditions with aluminum and manganese toxicities.

\section{Material and Methods}

\subsection{Plant Material}

The plant material consisted of 64 single hybrids derived from "Line $\times$ Tester" crosses between 20 tropical inbred lines with three testers (Cam inbgp117, 88069 and 9450) and between testers themselves, and one acid tolerant open pollinated variety (ATP-SR-Y) used as control. These lines were crossed in order to get hybrids with broad genetic bases, coming from parents presenting different levels of tolerance to soil acidity, their geographical origin diversity (IRAD, IITA, CIMMYT Cali and CIMMYT Colombia) and their varied colors, responding to users' choices (Table 1). 
Table 1. Origins and characteristics of the lines, testers and maize composite tested

\begin{tabular}{|c|c|c|c|c|c|}
\hline No. & Varieties & Origins & Genetic basis & $\begin{array}{l}\text { Presumed level of tolerance to } \\
\text { toxicity: aluminum-manganese }\end{array}$ & Grain colors \\
\hline 1 & ATP S6 33Y-1 & IRAD & ATP-SR & Tolerant-Tolerant & Yellow \\
\hline 2 & ATP S6 32Y-1 & IRAD & ATP-SR & Tolerant-Tolerant & Yellow \\
\hline 3 & ATP-Last & IRAD & ATP-SR & Tolerant-Tolerant & Yellow \\
\hline 4 & ATP-46 & IRAD & ATP-SR & Tolerant-Tolerant & Yellow \\
\hline 5 & ATP-43 & IRAD & ATP-SR & Tolerant-Tolerant & Yellow \\
\hline 6 & D 506-3 & CIMMYT & n.d. & n.d. & Yellow \\
\hline 7 & D 506-4 & CIMMYT & n.d. & n.d. & Yellow \\
\hline 8 & Ku 1414 & IITA & n.d. & Tolerant-Tolerant & Yellow \\
\hline 9 & 87036 & IRAD & TMZsr $\times$ pop32 & Tolerant -Tolerant & White \\
\hline 10 & CLA 154 & CIMMYT & n.d. & n.d. & Yellow \\
\hline 11 & CLA 106 & CIMMYT & n.d. & Tolerant-Tolerant & Yellow \\
\hline 12 & ATP-14 & IRAD & n.d. & n.d. & Yellow \\
\hline 13 & CLA 18 & CIMMYT & n.d. & Intermediate-Tolerant & Yellow \\
\hline 14 & $\mathrm{Cml} 322$ & CIMMYT & n.d. & n.d. & White \\
\hline 15 & $\mathrm{Cml} 358$ & CIMMYT & Pop SA3 & Tolerant-Tolerant & Yellow \\
\hline 16 & 9450 & IITA & B73 & Intermediate-Tolerant & Yellow \\
\hline 17 & 88069 & IRAD & n.d. & n.d. & Yellow \\
\hline 18 & Cam Inb gp1 17 & IRAD & Suwan I-SR & Sensitive-Tolerant & Yellow \\
\hline 19 & C4RR SA3 & CIMMYT & n.d. & n.d. & Yellow \\
\hline 20 & C4RR SA4 & CIMMYT & n.d. & n.d. & Yellow \\
\hline 21 & C4SRR SA6 & CIMMYT & n.d. & n.d. & Yellow \\
\hline 22 & C4 SRR A7 & CIMMYT & n.d. & n.d. & Yellow \\
\hline 23 & CIgp1 $17(\mathrm{~F})$ & IRAD & Suwan I-SR & Tolerant-Tolerant & Yellow \\
\hline 24 & ATP-SR-Y & IRAD & ATP-SR & Tolerant-Tolerant & Yellow \\
\hline
\end{tabular}

Note. n.d.: not determined; CIMMYT: International Maize and Wheat Improvement Center; IRAD: Agricultural Research Institute for Development. IITA: International Institute of Tropical Agriculture; Pop: population; ATP: Acid Tolerant Population.

Source: Cameroon Inco Annual Repport Year 1999; The et al. (2006b).

\subsection{Experimental Sites and Chemical Propreties of Soils}

The first experimental site is located in the Central region (Nkolbisson, Yaoundé) and the second is located in the South region (Nkoemvone, Ebolowa), (Figure 1). In Nkolbisson $\left(3^{\circ} 44^{\prime} \mathrm{N} ; 11^{\circ} 36^{\prime} \mathrm{E}\right)$, the site is located $650 \mathrm{~m}$ above sea level. The annual average temperature was $23.5^{\circ} \mathrm{C}$, the rainfall is bimodal and the annual average is $1560 \mathrm{~mm}$. Classification show a soil with a clay-silty texture with a strong tendency to hydromorphy and manganese toxicity and is of the Kandiudox type. In Ebolowa, the experimental site, Nkoemvone $\left(2^{\circ} 40{ }^{\prime} \mathrm{N}\right.$; $12^{\circ} 24^{\prime} \mathrm{E}$ ) is located $25 \mathrm{~km}$ from the city, at $615 \mathrm{~m}$ above sea level. The average annual temperature is $24^{\circ} \mathrm{C}$ with a Guinean-type climate and a bimodal annual average rainfall of $1875 \mathrm{~mm}$. The soil had a clay texture and aluminum toxicity, classified in the Kandiudox type and belonging to oxisols (Welcker et al., 2005; Thé et al., 2005). Nkolbisson was characterized by acidic soil with manganese toxicity while in Nkoemvone, its acidity was linked to aluminum toxicity (Tekeu et al., 2015). 


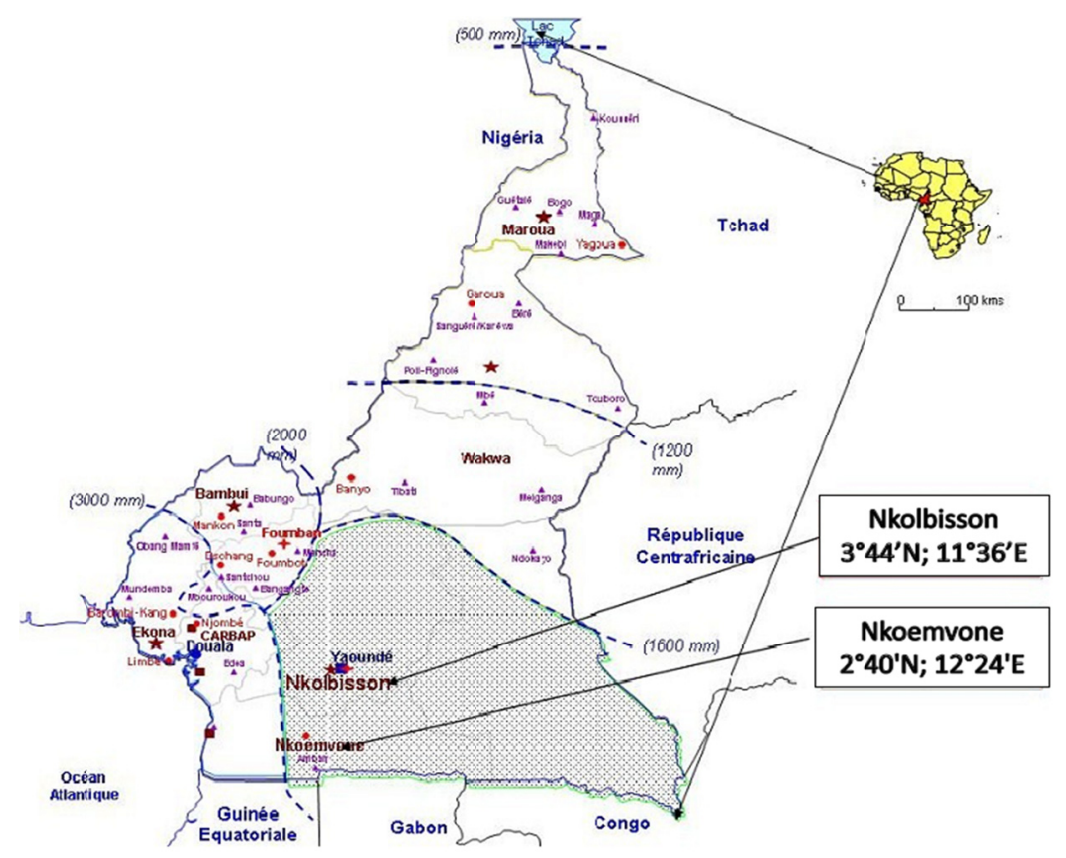

Figure 1. Position of the experimental sites in Cameroon (Ngonkeu, 2009)

\subsection{Phenotyping, Data Collection and Statistical Analysis}

Field trials were conducted in a completely randomized block design with three replicates on an area of $780 \mathrm{~m}^{2}$. Crosses and evaluations were made in 2010-2011 and 2011-2012, respectively. The planting was done at a density of 53,333 plants $\cdot \mathrm{ha}^{-1}$. The experimental unit was $4 \mathrm{~m}$ row lenght, with inter-row of $0.75 \mathrm{~m}$ and intra-row of $0.5 \mathrm{~m}$. The experiment received a basal dose of fertilizer of $37 \mathrm{~N}, 24 \mathrm{P}_{2} \mathrm{O}_{5}$ and $14 \mathrm{~K}_{2} \mathrm{O} \mathrm{kg} \cdot \mathrm{ha}^{-1}$ applied 10 days after planting and $46 \mathrm{~N} \mathrm{~kg} \cdot \mathrm{ha}^{-1}$, applied 30 days after planting (The et al., 2006).

The variables measured were: seedling emergence rate; appearance of the maize's ears in the field (the rating index varies from 1 to 5 , where the indices between 1 and 1.9; 2 and 2.9; 3 and 5 were respectively assigned to the best, average and bad aspects of the ears) was assessed at the physiological maturity stage of plants; plant prolificacy (the number of ears on a plant) as described by Welcker et al. (2005); the plant stand at harvest and the number of ears at harvest were also recorded. At harvest, all ears from each plot were counted and the number of ears per plant (EPP) was calculated using the formula: $\mathrm{EPP}=\mathrm{EC} / \mathrm{PC}$, Where $\mathrm{EC}$ and $\mathrm{PC}=$ number of ears and number of plants per row, respectively (Tandzi et al., 2015). Yield was adjusted to $15 \%$ moisture using the formula: GY $\left(\mathrm{t} \cdot \mathrm{ha}^{-1}\right)=\left[\right.$ Grain Weight $\left(\mathrm{kg} \cdot \mathrm{plot}^{-1}\right) \times 10 \times(100-\mathrm{MC}) /(100-15) /($ Plot Area $\left.)\right]$, where, $\mathrm{MC}=$ Grain Moisture Content (CIMMYT, 1985).

The analysis of the classification of the accessions was made through a multivariate analysis using the software SPSS version 16.0, based on the agro-morphological variables and the Pearson correlation was carried out by SAS 9.0 to establish interrelations between descriptors. Principal component analysis (PCA) was done using Spad version 5.0.

\section{Results}

\subsection{Chemical Composition of Soils}

In both sites, the results of the analysis showed soil pH below 5.5. In Nkolbisson, the pH was 5.12 while in Nkoemvone, it hardly exceeds 4.3 (Table 2). The soils also had low assimilable phosphorus values, between 4.65 $\mathrm{ug} \cdot \mathrm{g}^{-1}$ (Nkolbisson) and $7.55 \mathrm{ug} \cdot \mathrm{g}^{-1}$ (Nkoemvone) compared to the normal value for acid soils which was

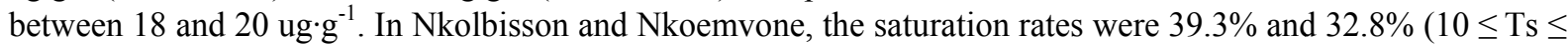
$50 \%$ ), respectively. Hence the acidity of Nkolbisson was characterized by manganese toxicity with a toxicity rate $96.1 \%(\mathrm{Tt}(\mathrm{Mn})>60 \%$ ) whereas in Nkoemvone, it was characterized by aluminum toxicity with a toxicity rate of $67.2 \%(\mathrm{Tt}>60 \%)$. 
Table 2. Chemical characteristics of Nkolbisson and Nkoemvone soils

\begin{tabular}{lll}
\hline \multirow{2}{*}{ Chemical composition } & Nkolbisson & Nkoemvone \\
\cline { 2 - 3 } $\mathrm{Ca}(\mathrm{cmol}(+) / \mathrm{kg})$ & $0-20 \mathrm{~cm}$ & $0-20 \mathrm{~cm}$ \\
$\mathrm{Mg}(\mathrm{cmol}(+) / \mathrm{kg})$ & 2.68 & 0.68 \\
$\mathrm{~K}(\mathrm{cmol}(+) / \mathrm{kg})$ & 0.72 & 0.2 \\
$\mathrm{Na}(\mathrm{cmol}(+) / \mathrm{kg})$ & 0.24 & 0.24 \\
$\mathrm{Al}(\mathrm{cmol}(+) / \mathrm{kg})$ & 0.05 & 0.013 \\
$\mathrm{CEC}(\mathrm{cmol}(+) / \mathrm{kg})$ & 0.52 & 2.32 \\
$\mathrm{Zn}(\mathrm{ppm}$ ou $\mathrm{ug} / \mathrm{g})$ & 9.4 & 3.45 \\
$\mathrm{Cu}(\mathrm{ppm}$ ou $\mathrm{ug} / \mathrm{g})$ & 4.73 & 0.533 \\
$\mathrm{Mn}(\mathrm{ppm}$ ou ug/g) & 3.08 & 1.75 \\
$\mathrm{Fe}(\mathrm{ppm}$ ou ug/g) & 90.6 & 6.49 \\
$\mathrm{P}(\mathrm{ppm} \mathrm{ou} \mathrm{ug} / \mathrm{g})$ & 414.67 & 113.35 \\
$\mathrm{~N}$ total $(\%)$ & 4.65 & 7.55 \\
$\mathrm{C}$ total $(\%)$ & 0.13 & 0.121 \\
$\mathrm{C} / \mathrm{N}$ & 1.81 & 1.13 \\
$\mathrm{PHeau}$ & 13.86 & 9.28 \\
$\mathrm{Ts}(\%)$ & 5.12 & 4.33 \\
$\mathrm{Tt}(\mathrm{Al} / \mathrm{Mn})(\%)$ & 39.25 & 32.84 \\
$\mathrm{Conclusion}$ & 96.13 & 67.18 \\
\hline
\end{tabular}

Note. Ts: saturation rate; $\mathrm{Tt}(\mathrm{Al} / \mathrm{Mn})$ : rate of aluminum/manganese toxicity.

\subsection{Agromorphological Characteristics of Accessions}

The Analysis of variance showed highly significant differences between different sites for the emergence rate, prolificacy and grain yield, and was not significant for the appearance of ears while between accessions, highly significant differences were observed for all traits (Table 3 ).

Table 3. Mean squares resulting from the Analysis of Variance

\begin{tabular}{llllll}
\hline Source of variations & $\mathrm{df}$ & $\mathrm{TL}$ & $\mathrm{PR}$ & $\mathrm{AE}$ & $\mathrm{GYD}$ \\
\hline Environment & 1 & $4645.70^{* * *}$ & $1.51^{* * *}$ & $0.39 \mathrm{~ns}$ & $3.18 \mathrm{~ns}$ \\
Accessions & 63 & $522.21^{* * *}$ & $0.15^{* * *}$ & $0.76^{* * *}$ & $11.28^{* * *}$ \\
Error & 702 & 200.81 & 0.05 & 0.31 & 4.75
\end{tabular}

Note. df: degree of freedom; GYD: grain yield; TL: emergence rate; PR: prolificacy; AE: appearance of the ear. ***: significant at $\mathrm{P}<0.0001$; ns: not significant at $\mathrm{P}>0.05$.

The result of the principal component analysis (PCA) explained the genetic diversity in our maize collection in Nkoemvone (Figure 2) and Nkolbisson (Figure 3). The "eigenvalues" measure the importance and the contribution of the component in the total variance, while each eigenvector coefficient indicates the degree of contribution of each original variable with which the main component is associated. The largest of the coefficients, whatever its sign (positive or negative), is the most efficient at discriminating accessions. There is no standard test to prove the significance of eigenvalues and coefficients. In this study, the PCA grouped the nine (9) variables (Table 4): Number of plants stand (Pst), emergence rate (TL), number of plants at harvest (PH), number of ears at harvest (PE), prolificacy of plants (PR), appearance of the ear (AE), weight of ears (EW), moisture content of seeds $(\% \mathrm{M})$ and grain yield (GYD). Indeed, the first two components report $79 \%$ of the variation in Nkolbisson and $73.6 \%$ in Nkoemvone. Table 1 and Figure 2 show that in Nkolbisson, the main component 1 (PC1) is associated with Pst, TL, PH, EH and EW accounting for $67.0 \%$ of the total variation while PC2 is associated mainly with PR , EA, $\% \mathrm{M}$ and GYD accounting for $12 \%$ of the total change. In Nkoemvone, PC1 is associated with Pst, TL, PH, EH, EW and GYD with $60.3 \%$ of the total variation while PC2 is coupled with PR, EA, and $\% \mathrm{M}$ with $13.3 \%$ of the total variance. 
Table 4. Coefficients of the eigenvalues and vectors associated with the main component of the different agro morphological descriptors

\begin{tabular}{|c|c|c|c|c|}
\hline & \multicolumn{4}{|c|}{ Eigenvectors } \\
\hline & \multicolumn{2}{|c|}{ Nkolbisson } & \multicolumn{2}{|c|}{ Nkoemvone } \\
\hline & $\mathrm{PC}_{1}$ & $\mathrm{PC}_{2}$ & $\mathrm{PC}_{1}$ & $\mathrm{PC}_{2}$ \\
\hline Eigenvalues & 6.033 & 1.075 & 5.428 & 1.195 \\
\hline Total variance $(\%)$ & 67.044 & 11.951 & 60.317 & 13.287 \\
\hline Cumulative (\%) & 67.044 & 78.999 & 60.317 & 73.604 \\
\hline \multirow[t]{2}{*}{ Cumulative eigen values } & 6.033 & 7.1 & 5.428 & 6.624 \\
\hline & \multicolumn{4}{|c|}{ Eigenvalues } \\
\hline Pst & 0.963 & 0.119 & 0.886 & 0.329 \\
\hline TL & 0.963 & 0.119 & 0.886 & 0.329 \\
\hline PH & 0.969 & 0.144 & 0.942 & 0.126 \\
\hline $\mathrm{EH}$ & 0.941 & -0.093 & 0.905 & 0.349 \\
\hline PR & -0.353 & -0.668 & -0.105 & 0.627 \\
\hline EA & -0.655 & 0.273 & -0.699 & 0.438 \\
\hline EW & 0.945 & -0.121 & 0.882 & -0.337 \\
\hline$\% \mathrm{M}$ & -0.104 & 0.673 & -0.299 & 0.144 \\
\hline GYD & 0.944 & -0.164 & 0.883 & -0.345 \\
\hline Var. Exp & 6.033 & 1.075 & 5.428 & 1.195 \\
\hline Prp. Tot & 0.67 & 0.11 & 0.603 & 0.132 \\
\hline
\end{tabular}

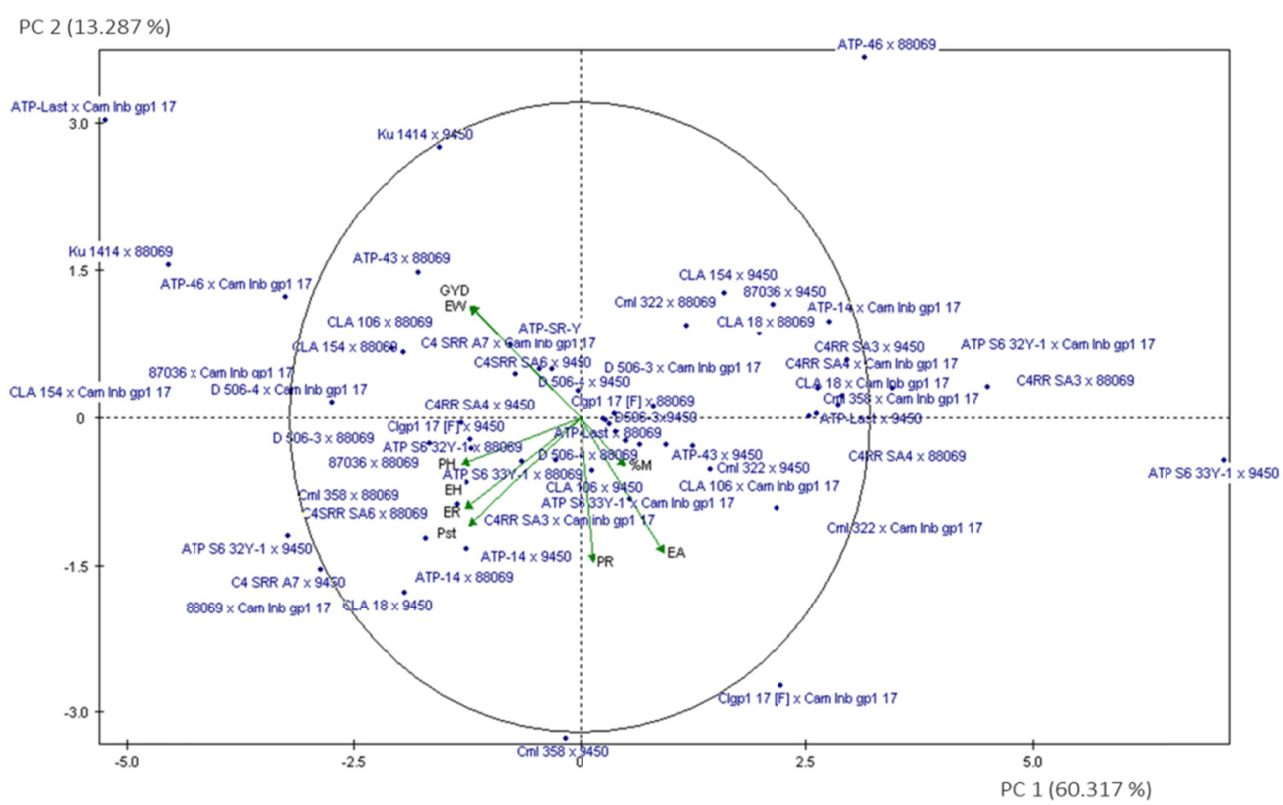

Figure 2. Principal Component Analysis of descriptors in maize cultivars at the Nkoemvone site 


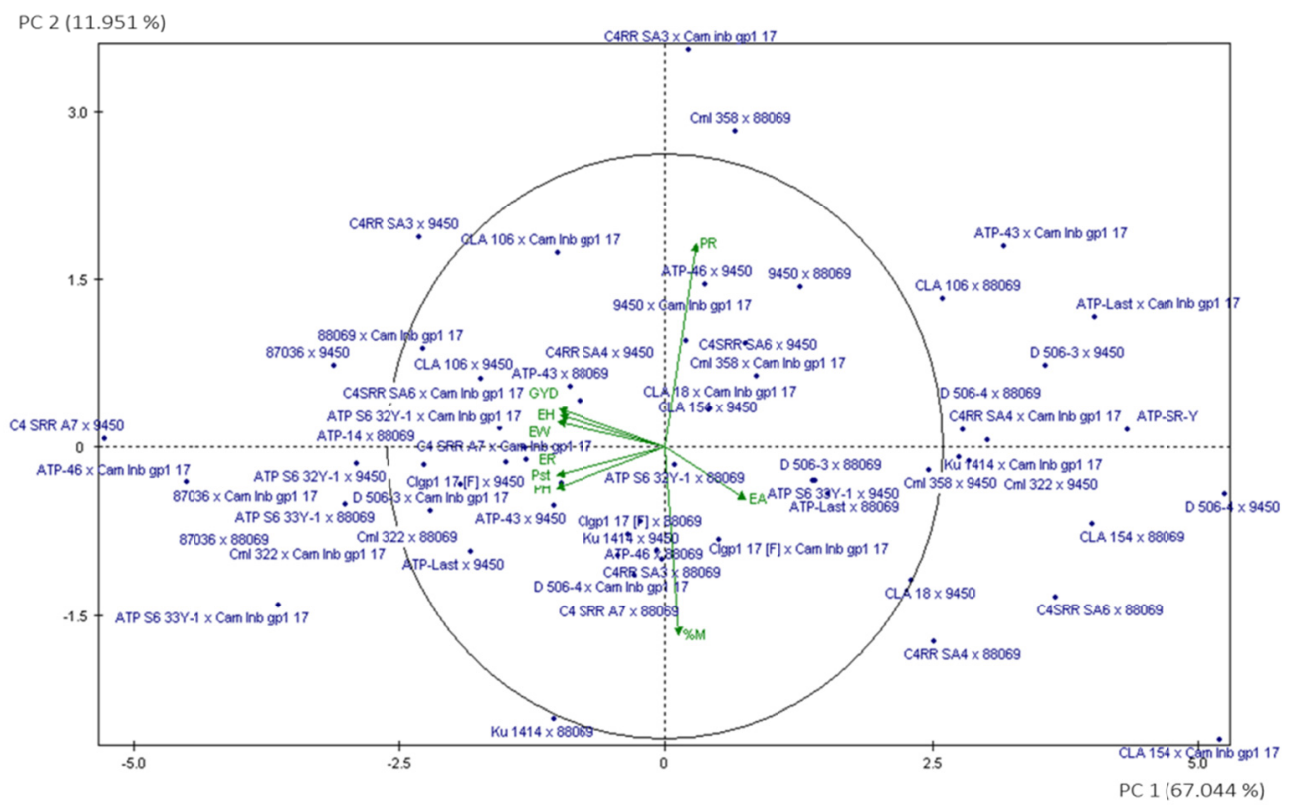

Figure 3. Principal Component Analysis of descriptors in maize cultivars at the Nkolbisson site

\subsection{Grouping and Agro-morphological Characterization}

In order to characterize the accessions of maize cultivated on acid soils in humid forest zone, an Hierarchical Clustering Analysis was carried out, based on the agro-morphological characters presented by each accessions. Indeed, the cross-section of the dendrogram at the points of dissimilarity at $12.0 \%$ and $4.5 \%$ respectively in Nkoemvone and Nkolbisson reveals that the 64 varieties evaluated on acid soil formed 4 distinct groups in each study site (Figures 4 and 5). Each of the groups showed clear specific features for which the performance differs from that of the others (Table 5).

Table 5. Average values of the variables by group of accessions on acid soil at the two sites

\begin{tabular}{|c|c|c|c|c|c|c|c|c|}
\hline \multirow{2}{*}{ Variables } & \multicolumn{2}{|c|}{ Group 1} & \multicolumn{2}{|c|}{ Group 2} & \multicolumn{2}{|c|}{ Group 3} & \multicolumn{2}{|c|}{ Group 4} \\
\hline & Nkoemvone & Nkolbisson & Nkoemvone & Nkolbisson & Nkoemvone & Nkolbisson & Nkoemvone & Nkolbisson \\
\hline $\mathrm{TL}$ & 57.24 & 46.96 & 35.76 & 25.58 & 35.18 & 29.01 & 64.81 & 20.78 \\
\hline PR & 0.96 & 1.14 & 1 & 1.50 & 0.76 & 2.02 & 0.75 & 0.90 \\
\hline $\mathrm{AE}$ & 1.86 & 2.04 & 2.31 & 2.48 & 2 & 2.17 & 1.5 & 2.64 \\
\hline GYD & 5.28 & 5.98 & 3.2 & 3.27 & 2.62 & 4.28 & 11.67 & 2.61 \\
\hline
\end{tabular}

Note. TL: emergence rate; PR: prolificacy; AE: appearance of the ear; GYD: grain yield. The bold numbers indicate the high values observed for each variable at each site.

\subsubsection{Nkoemvone Site}

In Nkoemvone, group 1 is made up of 45 accessions (Figure 4). These are varieties characterized mainly by average emergence rates $(57.6 \%)$, indicating that about $50 \%$ of plants emerge at the stage of 14 days after planting. They have a low prolificacy (0.96). In addition, at maturity, their ears have good appearance (1.86) and they produce average yields of $5.28 \mathrm{tha}^{-1}$ on acid soil. For these reasons, this group of accessions can be qualified as tolerant varieties. Group 2 contains 16 maize accessions. In view of the results, these are accessions characterized by low emergence rates (35.75\%), indicating the difficulty experienced by the plants to emerge at the stage of 14 days after planting. Their prolificacy is high (1), indicating that they generally produce one ear per plant on acid soil, and whose interval between male and female flowerings is short. At maturity, their ears look bad (2.31) compared to the other groups and they produce yields of around $3.20 \mathrm{t}^{\mathrm{ha}} \mathrm{ha}^{-1}$ on acid soil. They can therefore be classified as sensitive cultivars. In addition, the 2 accessions belonging to group 3 show relatively low emergence rates (35.18\%), indicating that most plants do not emerge at the stage of 14 days after planting. Their prolificacy is low $(0.75)$, showing that they produce at most one ear per plant. They also produce spikes of poor appearance (2), compared to the other groups, and give yields of around $2.62 \mathrm{t} \cdot \mathrm{ha}^{-1}$. For these reasons, they 
can be considered as varieties very sensitive to acidic soils under aluminum toxicity. Group 4 is essentially made up of a single hybrid. It is characterized by early emergence (64.81\%) at the stage of 14 days after planting and producing at most one ear per plant (0.76). In addition, it has better looking ears (1.5) and is highly productive with a yield of $11.67 \mathrm{t}^{\mathrm{h}} \mathrm{h}^{-1}$. In view of these results, this group consisting of a single hybrid can be selected as a variety very tolerant of acidic soils under aluminum toxicity.

\subsubsection{Nkolbisson Site}

In Nkolbisson, group 1 is made up of 36 varieties (Figure 5). Compared to the other groups on the site, they have the best emergence rates (47\%) and at maturity, their ears have good aspects (2.04). They have a high prolificacy (1.13), that is to say that they produce on average at least one spike per plant, indicating the approximation between the dates of male and female flowering. In other words, they have a strong potential for adaptation in acidic soil under manganic toxicity conditions. Also, their ears show better aspects (2.0) and they produce the highest yields $\left(6 \mathrm{t}^{\mathrm{h}} \mathrm{ha}^{-1}\right)$. For this, they can be considered as very tolerant accessions to acid soils under manganese toxicity.

As for group 2, it consists of 16 accessions, characterized by low lift rates (25.6\%). They have high prolificities (1.44), showing that they produce on average at least one ear by plant. Their ears do not show good aspects (2.48) and also, they produce low yields $\left(3.3 \mathrm{t} \cdot \mathrm{ha}^{-1}\right)$. Thus, they can be considered as susceptible varieties.

Regarding the group 3, it has 3 accessions. These accessions are very affected by soil acidity during the first 14 days after planting because their emergence rates are very low (29.0\%) but, they have the highest potential for ear production on acid soil with prolificities of the order of 2.0. They produce on average at least two ears of maize per plant. These results suggest that the interval between male and female flowering is very short, favoring timely fertilization. Compared to other groups, its ears have moderately good appearance (2.2) and produce average yields of $4.3 \mathrm{t}^{\mathrm{h}} \mathrm{ha}^{-1}$. For these reasons, this group of accessions can be qualified as tolerant varieties.

In addition, group 4 includes 9 accessions, characterized by a low capacity to adapt under acidic soil conditions. They have shown that they are very affected in acidic environments through low values obtained for each agro-physiological characteristic measured. Under these conditions, the emergence of the plants is very slow and they are unable to carry a large amount of ears because their emergence rates and prolificities are $20.78 \%$ and 0.9 respectively. In addition, their ears have moderately good appearance (2.64) and they produce very low yields $\left(2.61 \mathrm{t}^{\mathrm{h}} \mathrm{h}^{-1}\right)$. Thus, they can be classified as a very susceptible variety under the conditions of acid soils under manganese toxicity (Figure 3).

In order to determine the selection criteria for maize varietal under uncorrected acid soil conditions, a phenotypic correlation analysis was made between the emergence rate (TL), prolificacy (PR), ear appearance (AE) and grain yield (GYD) at the Nkoemvone and Nkolbisson sites (Table 6). Indeed, the correlation coefficients (r) vary highly depending on the trait. Under acidic soil conditions, the yield shows a positive and highly significant correlation with TL in Nkoemvone $(\mathrm{r}=0.61)$ and Nkolbisson $(\mathrm{r}=0.84)$, which indicates that the acceleration of the emergence of seedlings leads to high yield.

Also, negative and highly significant correlations were observed between TL and AE in Nkoemvone $(\mathrm{r}=-0.41)$ and Nkolbisson $(r=-0.49)$. Between PR and TL, a negative and highly significant correlation was observed in Nkolbisson $(\mathrm{r}=-0.38)$ while in Nkoemvone, it was not significant. In addition, the Pearson's correlations observed between the PR and the AE was not significant whereas between the PR and the GYD, they are significant in Nkoemvone $(r=-0.14)$ and in Nkolbisson $(r=-0.21)$. Also, positive and highly significant correlations were found between the GYD and AE in Nkoemvone $(r=0.73)$ and in Nkolbisson $(r=0.68)$. Thus, these correlations observed indicate the direct link between the yield and the agronomic traits (TL, PR and AE).

Table 6. Phenotypic correlation (Pearson coefficient) between the variables evaluated on uncorrected acidic soil in the two study sites

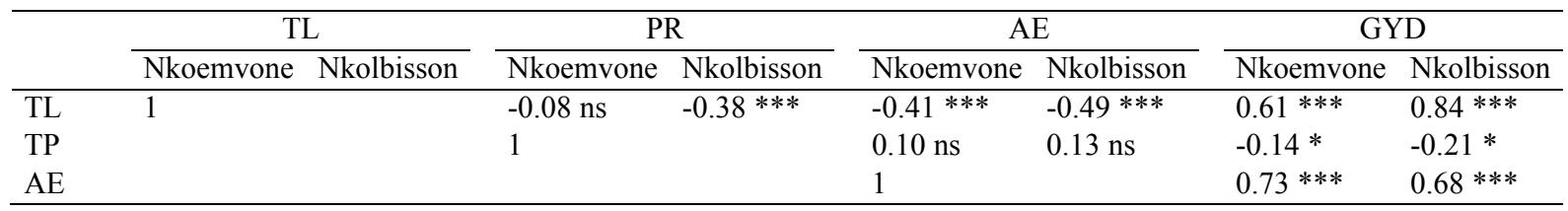

Note. ${ }^{* * *}$ : significant at $\mathrm{P}<0.0001 ;{ }^{*}$ : significant at $\mathrm{P}<0.05$; ns: not significant at $\mathrm{P}>0.05$. TL: seed emergence rate; PR: prolificity; AE: appearance of the ear; GYD: grain yield. 


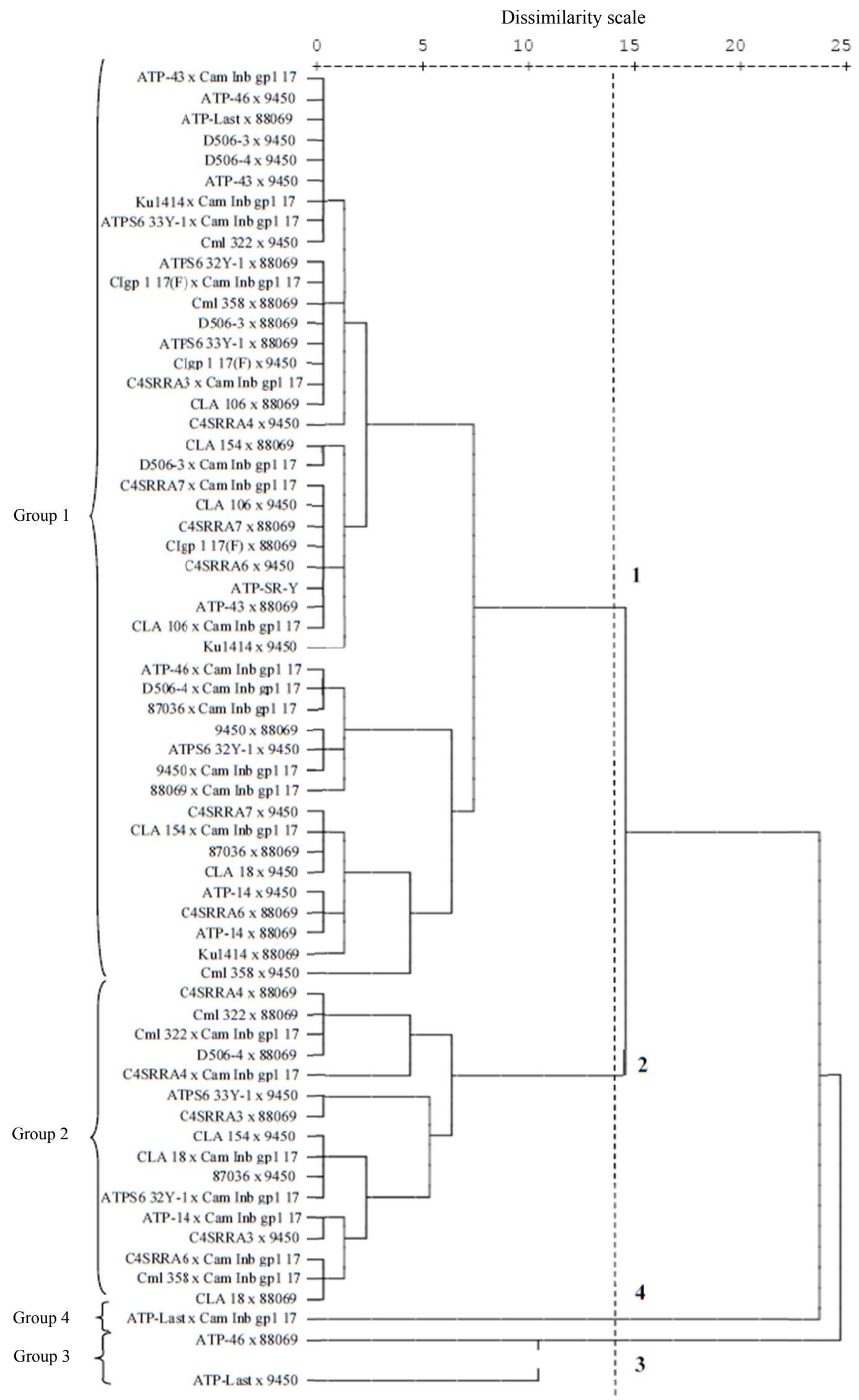

Figure 4. Dendrogram of the classification of 64 hybrid maize accessions evaluated on acid soil of Nkoemvone. The vertical dotted line represents the reference points for the delimitation of groups 1, 2, 3 and 4 


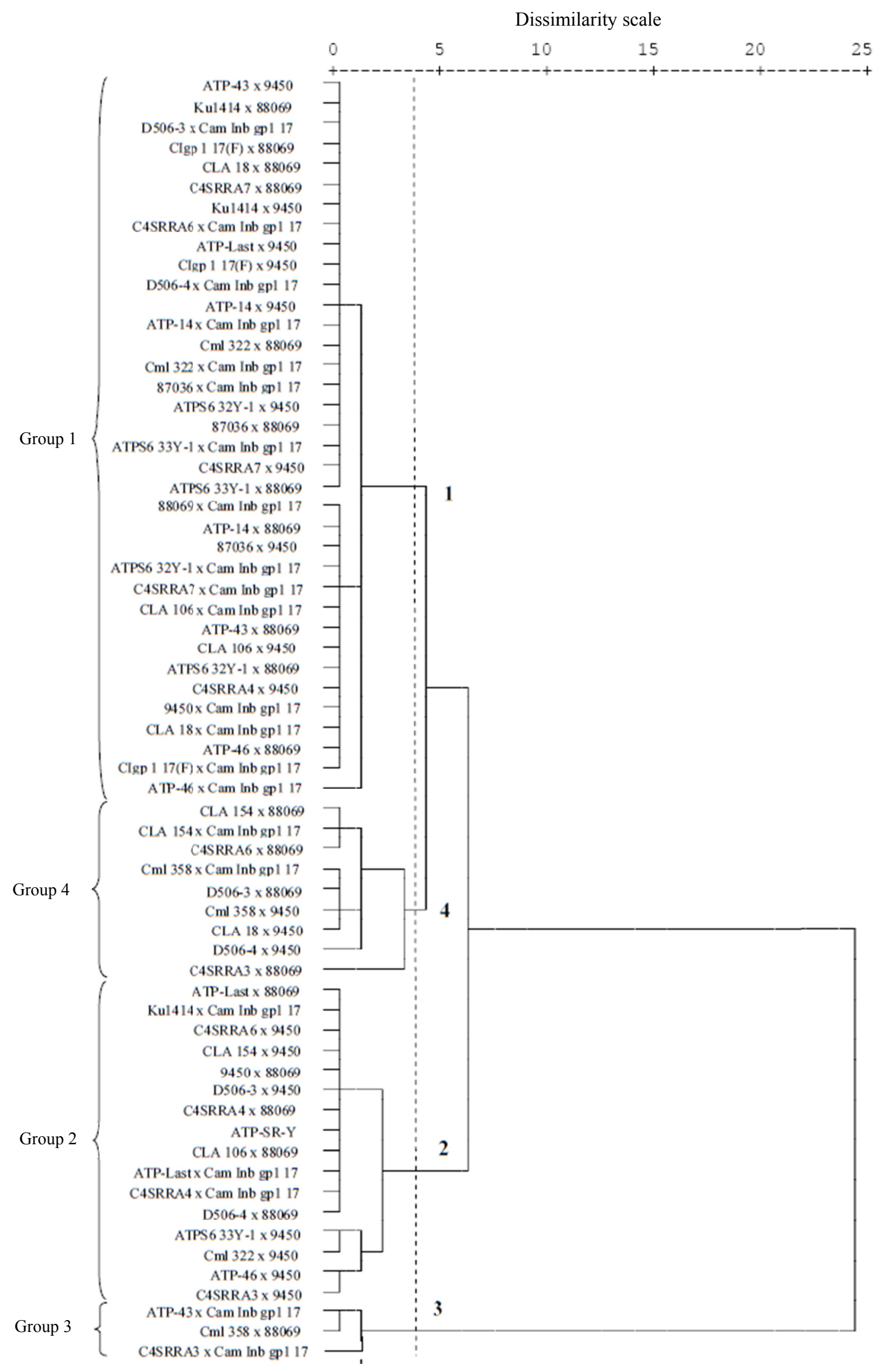

Figure 5. Dendrogram of the classification of 64 hybrid maize accessions evaluated on acid soil of Nkolbisson. The vertical dotted line represents the reference points for the delimitation of groups 1,2,3 and 4 


\section{Discussion}

\subsection{Chemical and Ecological Aspect of Soils}

Chemical analyzes of the soils have shown that the $\mathrm{pH}$ values are below 5.5, indicating that these soils are very acidic as previously demonstrated by Robain (1993). These results confirm the statements of certain authors (Ambassa-Kiki et al., 2002; Bindzi Tsala, 1987) who showed that 75 to $100 \%$ of the land in the forest area of Cameroon is acidic. In addition, these results are similar to the data reported in the Centre's Cameroon region by certain authors (Thé et al., 2006b; Ngonkeu, 2009) who found that the soils of the humid forest zone with bimodal rainfall are very acidic $(4.52 \leq \mathrm{pH} \leq 5.12)$.

Indeed, acid rain also contributes to soil acidification. This is because tropical soils are high in sesquioxides and are already very acidic, so the contribution of acidic precipitation has little effect on $\mathrm{pH}$ (Harter, 2007).

The soils studied have low assimilable phosphorus values, compared to the normal value (Mémento de l'Agronome, 2006). These results could be explained by the fact that under acidic conditions, phosphorus is present in the form of poorly soluble compounds such as iron phosphate, aluminum phosphate and occluded phosphorus (Dabin, 1963). To maintain a stock of phosphate in assimilable form, sufficient for the needs of plants, a supply of fertilizer or dolomitic lime is necessary.

Regarding the site effect, highly significant differences were observed between the two study sites, for the traits emergence rate and prolificity, where the highest values were obtained in Nkolbisson, suggesting that acidic soils under aluminum toxicity delay the growth of plants in the juvenile state and reduces the production of the number of ears. These results are consistent with data reported in hydroponic solution by some authors (Sierra et al., 2003; Krill et al., 2010; Krstic et al., 2012) who showed that aluminum delays the growth of the primary root and inhibits the formation of lateral roots, limiting the yield by reducing the absorption of water and nutrients in the soil.

\subsection{Characterization of Accessions and Correlations Between Variables}

Analyzes based on the classification of maize accessions have shown that the sixty-four accessions can form four discriminating groups. Each group has its own characters which could be used to describe the group. Indeed, in Nkolbisson, the cultivars of group 1 are tolerant because of their good performance on acid soil. Among the thirty-six hybrids in this group, fourteen have parents from IRAD, one comes from a cross between two parents from IITA and twenty-one have parents of various origins. They have presumed levels of acid tolerance and different genetic bases. Furthermore, the cultivars of groups 2 and 3 are varieties with low emergence rates, good prolificities and spikes of good appearance. The varieties of group 4 had low yields because of their susceptibility on acid soil with manganese toxicity. Of the nine varieties in this group, six come from crosses between CIMMYT and IRAD cultivars and three are from the crosses between CIMMYT and IITA varieties. In Nkoemvone, the cultivars of group 2 and 3 presented bad-looking ears. Indeed, all the energy expended in the emergence stage led to the low grain yields produced by these accessions in this study. These results are similar to the data obtained by Sobda et al. (2013), who indicated that cowpea varieties which take longer in the juvenile stage produce less yield in the Sudano-Sahelian zone of Cameroon. Group 1 accessions exhibited poor prolificacy. They had difficulty completing their development cycle properly because of the long interval between male and female flowering. This result is not consistent with the data reported by Summerfield et al. (1985) who pointed out that seeds that produce good yields are generally varieties with short flowering periods. In addition, early maturity is recognized as a relatively important agronomic feature in the plant breeding program (Rachie, 1985). The better yields obtained by the group 4 hybrid result from its potential. Indeed, it has a large genetic base (ATP-SR and Swan I-SR) and its parents (ATP-Last and Cam Inb gp1 17) are recognized by IRAD as tolerant varieties to acid soils (The et al., 2006).

On the basis of the relationships between the descriptors, highly significant correlations observed between the agro-morphological characteristics (emergence rate, prolificity and appearance of the ear) and the grain yield confirm the statements of Ouedraogo et al. (2008) who showed that the Vigna subterranea L. plants which take longer in the vegetative stage produce less yield under the conditions of semi-arid soil in Burkina Faso.

Agro-morphological traits such as plant emergence rate, prolificacy, ear appearance and grain yield have been found as important phenotypic markers for assessing the genetic diversity of germplasm. These descriptors should be considered by maize varietal improvement programs in Cameroon. Multivariate analyzes have made it possible to describe the variability between the varieties used. However, molecular characterization of the cultivars in each group could provide additional information on the genetic basis of these accessions. 


\section{Conclusion}

The characterization of the sixty-four accessions provided phenotypic information to users of these new varieties of maize hybrids. Despite their diversity and varied origins, these hybrid's varieties of maize evaluated on acidic soils can be classified into four main groups, based on the agro-morphological characteristics presented by each variety in Nkoemvone and Nkolbisson. Morphological characters such as plant emergence rate, prolificacy, ear appearance and grain yield have been found as important phenotypic markers for assessing genetic diversity and germplasm. These descriptors should necessarily be considered by breeding programs, varietal discrimination and formulation of maize cores for tolerance to acidic soils with aluminum and manganese toxicities. The multivariate technique, PCA, used in this study effectively described the variability for descriptors in varieties of those maize accessions. However, molecular characterization of the cultivars in each group could provide additional information on the genetic basis of these accessions.

\section{Acknowledgements}

This collaborative work was funded by the Gates Foundation, through the West Africa Center for Crop Improvment (WACCI) project. We thank CIMMYT and IRAD for providing us with genetic material and their technical assistance, and IITA for the soil analyzes.

\section{References}

Adregbola, P. (1994). Expérience et acquis paysans au Sud du Bénin. In CIRAD (Ed.), Production et valorisation du maïs à l'échelon villageois en Afrique de l'Ouest (pp. 14-19). CIRAD-ORSTOM.

Aldrich, S. R., Scott, W. O., \& Leng, E. R. (1975). In modern corn production. Champain, IL.A \& L Publication.

Ambassa-Kiki, R., Yemefack, M., \& Tchienkoua. (2002). Caractéristique biophysique et aptitude à la production végétale, animale et piscicole (pp. 8-48). IRAD, Yaoundé.

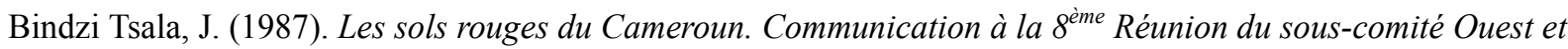
centre africain de corrélation des sols pour la mise en valeur des Terres (p. 201). Mesires-FAO, Yaoundé.

Borrero, J. C., Pandey, S., Ceballos, H., Mangnavaca, R., \& Bahia, A. F. C. (1995). Genetic variances for tolerance to soil acidity in tropical maize population. Maydica, 40, 283-288.

CIMMYT. (1985). Managing trials and reporting data for CIMMYT international maize testing program. Mexico, DF: CIMMYT.

Clark, R. B. (1997). Arbuscular mycorrhizal adaptation, spore germination, root colonization, and host plant growth and mineral acquisition at low pH. Plant and Soil, 192, 15-22. https://doi.org/10.1023/ A:1004218915413

Claudia, L. (2000). Field and laboratory screening of maize (Zea mays L.) cultivars for adaptation on an acid Al-toxic Soil in Guadeloupe (p. 71, Diploma thesis, University of Hannover, Germany).

Dabin, B. (1963). Appréciation des besoins en Phosphore dans les sols de Côte-d'Ivoire. Cah. ORSTOM, Sér. Pédol., 3, 27-42.

Eswaran, H., Reich, P., \& Beigroth, F. (1997). Global distribution of soils with acidity. In R. Schaffert \& A. Moniz (Eds.), Plant Soil Interaction at Low pH (pp. 159-164). Kluwer Acad. Publ., Netherlands.

Horst, W. J., Püsched, A. K., \& Schmoll, N. (1997). Induction callose formation is a sensitive marker for genotypic aluminium sensitivity in maize. Plant and Soil, 192, 23-30. https://doi.org/10.1023/A:10042 04120863

Karanja, J., Amugune, N. O., Ininda, J., Kimatu, J. N., \& Danson, W. J. (2009). Microsatellite analysis of the correlation between molecular and morphological traits in assorted maize inbred lines. African Crop Science Journal, 17(3), 133-144. https://doi.org/10.4314/acsj.v17i3.54213

Krill, A. M., Kirst, M., Kochian, L. V., Buckler, E. S., \& Hoekenga, O. A. (2010). Association and Linkage Analysis of Aluminum Tolerance Genes in Maize. PLOS ONE, 5(4), e9958. https://doi.org/10.1371/ journal.pone.0009958

Krstic, D., Ivica, D., Dragoslav, N., \& Dragana, B. (2012). Aluminium in Acid Soils: Chemistry, Toxicity and Impact on Maize Plants. Food Production-Approaches, Challenges and Tasks. IntechOpen. https://doi.org/10.5772/33077 
Mapiemfu, L. D., Thé, C., Tsoata, E., Zonkeng, C., \& Mfopou, M. Y. C. (2011). Inhibition de la croissance et du rendement du maïs (Zea mays L.) en sols très acides au Cameroun, et identificationde critères précoces de tolérance à la toxicité. Tropicultura, 29(2), 94-100.

Mémento de l'Agronome. (2006). Edition CIRAD-GRET (p. 1690). Ministère des Affaires Étrangères.

Mossor-Pietraszewska, T. (2001). Effect of aluminium on plant growth and metabolism. Acta Biochimica Polonica, 48, 673-686. https://doi.org/10.18388/abp.2001_3902

Ngonkeu, M. E. L. (2009). Tolérance de certaines variétés de maïs aux sols à toxicité aluminique et manganique du Cameroun et diversités moléculaire et fonctionnelle des mycorhizes à arbuscules (pp. 1-255, Thèse de Doctorat $\mathrm{PhD}$, Université de Yaoundé I, Cameroun).

Ngonkeu, M. E. L., Thé, C., Chaintreuil, C., Amougou, A., Dreyfus, B., Owona, A., \& Kuate, J. (2009). Diversité mycorhizienne du sisongo sauvage (Panicum maximum) et amélioration des rendements de deux variétés contrastées de maïs sur sols à toxicité en Al et Mn du Sud Cameroun (p. 64). Cameroon Biosciences Society.

Ouedraogo, M., Ouedraogo, J. T., Tignere, J. B., Balma, D., Dabire, C. B., \& Konate, G. (2008). Characterization and evaluation of accessions of Bambara groundnut (Vigna subterranea (L.) Verdcourt) from Burkina Faso. Science \& Nature, 5(2), 191-197. https://doi.org/10.4314/scinat.v5i2.42164

Petmi, C. L., Ngonkeu, E. L. M., Tandzi, N. L., Ambang, Z., Boyomo, O., Bell, J. M., ... Noé, W. (2016). Screening of maize (Zea mays L.) genotypes for adaptation on contrasted acid soils in the humid forest zone of Cameroon. Journal of Experimental Agriculture International, 14(6), 1-15. https://doi.org/10.9734/JEAI/ 2016/29333

Rachie, K. O. (1985). Introduction to Cowpea Research, Production and Utilization (pp. 21-26). John Wiley and Sons, Chichester.

Ranum, P., Peña-Rosas, J. P., \& Garcia-Casal, M. N. (2014). Global maize production, utilization, and consumption. Ann. N. Y. Acad. Sci., 1312, 105-112. https://doi.org/10.1111/nyas.12396

Robain, H. (1993). Caractérisation et classification des sols de la zone forestière humide.

Sierra, J., Noël, C., Dufour, L., Ozier-Lafontaine, H., Desfontaine, L., \& Welcker, C. (2003). Mineral nutrition and growth of tropical maize as affected by soil acidity. Plant Soil, 252, 215-226. https://doi.org/ 10.1023/A:1024713127053

Sobda, G., Wirnkar, L. V., \& Amadou, L. (2013). Characterization of Some Traditional Cowpea Varieties Grown by Farmers in the Soudano-Sahelian Zone of Cameroon. International Journal of Agriculture and Forestry, 3(4), 170-177.

Summerfield, R. J., Pate, J. S., Roberts, E. H., \& Wien, H. C. (1985). The physiology of cowpea. In S. R. Singh \& K. O. Rachie (Eds.), Cowpea Research, Production and Utilization (pp. 65-101). John Wiley and Sons, UK.

Tandzi, N. L. (2005). Contribution des lignées endogames introduites à l'amélioration du maïs (Zea mays L.) sur sols acides. Mémoire en vue de l'obtention du Diplôme d'Etudes Approfondies (D.E.A.) (p. 48). Département de Biologie et Physiologie Végétales, Université de Yaoundé I, Yaoundé, Cameroon.

Tandzi, N. L., Mutengwa, C. S., Ngonkeu, E. L. M., \& Gracen, V. (2018). Breeding Maize for Tolerance to Acidic Soils: A Review. Agronomy, 8, 84. https://doi.org/10.3390/agronomy8060084

Tandzi, N. L., Ngonkeu, E. L. M., Youmbi, E., Nartey, E., Yeboah, M., Gracen, V., ... Mafouasson, H. A. (2015a). Agronomic performance of maze hybrids under acid and control soil conditions. Int. J. Agron. Agric. Res., 6, 275-291.

Tandzi, N. L., Ngonkeu, M. E. L., Nartey, E., Yeboah, M., Mafouasson, H. A., Moche, K., ... Gracen, V. (2015b). Morphological characterization of selected maize (Zea mays L.) Inbred lines under acid soil conditions. International Journal of Current Research, 7(5), 15538-15544. https://doi.org/10.5376/mgg.2015.06.0002

Tandzi, N., L., \& Mutengwa, C. S. (2020). Estimation of Maize (Zea mays L.) Yield Per Harvest Area: Appropriate Methods. Agronomy, 10, 29. https://doi.org/10.3390/agronomy10010029

Tekeu, H. (2013). Evaluation des hybrides de maïs (Zea mays L.) pour la tolerance aux sols acides à toxicité aluminique et manganique en zones forestieres humides (p. 87, Mémoire de Master, Université de Yaoundé I, Cameroon). 
Tekeu, H., Ngonkeu, E. L. N., Tandzi, N. L., Djocgoue, P. F., Bell, J. M., \& Fokom, R. (2015). Evaluation of Maize (Zea mays L.) Accessions Using Line $\times$ Tester Analysis for Aluminum and Manganese Tolerance. International Journal of Biological and Chemical Sciences, 9, 2161-2173. https://doi.org/10.4314/ ijbcs.v9i4.36

Thé, C., Calba, H., Zonkeng, C., Ngonkeu, E. L. M., Adetimirin, V. O., Mafouasson, H. A., ... Horst, W. L. (2006b). Response of maize grain yield to changes in acid characteristics after soil amendements. Plant and Soil, 284, 45-57. https://doi.org/10.1007/s11104-006-0029-9

Thé, C., Nwaga, D., Ngonkeu, E. M., Mafouasson, H. A., \& Meka, S. S. (2007). Les contraintes à la production agricole en Afrique du Centre et de l'Ouest: Cas du maïs. In D. Nwaga, S. Hamon, C. Djieto Lordon, \& F. Engelmann (Eds.), Biotechnologies et maitrise des intrants agricoles en Afrique centrale. IRD, IRAD, Cameroun.

Thé, C., Tandzi, N. L., Zonkeng, C., Ngonkeu, E. L. M., Meka, S., Leon, C., \& Horst, W. J. (2005). Contribution of introduced inbred lines to maize varietal improvement for acid soil tolerance. In B. Badu-Apraku, M. A. B. Fakorede, A. F. Lum, A. Menkir, \& M. Ouedraogo (Eds.), Demand-driven technologies for sustainable maize production in west and central Africa. IITA-Cotonou, Bénin, International Institute of Tropical Agriculture (IITA).

Undie, U. L., Uwah, D. F., \& Attoe, E. E. (2012). Effect of intercropping and crop arrangement of yield and productivity of late season maize/soybean mixtures in the humid environment of South Southern Nigeria. $J$. Agric. Sci., 4, 37-50. https://doi.org/10.5539/jas.v4n4p37

USAID. (2013). Micronutrient Programs and DSM Nutritional Products. Maize Flour/Meal: 2002. Fortification Basics. Retrieved December 22, 2013, from https://www.dsm.com/en_US/nip/public/home/downloads/ Corn.pdf

Van Ranst, E., Verloo, M., Demeyer, A., \& Pauwels, J. M. (1999).. Analytical methods for soils and plants equipment and management of consumables. Manual for the soil chemistry and fertility laboratory. Laboratory of Analytical Chemistry and Applied Ecochemistry, University of Ghent.

Velasquez, P. C. J., Lopes de souza, C., Narro, A. L., \& Pandey, S. (2008). Genetic effects for maize traits in acid and non-acid soils. Genetics and Molecular Biology, 31, 89-97. https://doi.org/10.1590/S1415-4757 2008000100017

Welcker, C., Thé, C., Andreau, B., De Leon, S. N., Parentoni, J., Bernal, J., ... Horst, W. J. (2005). Heterosis and Combining Ability for Maize Adaptation to Tropical Acid Soils: Implications for Future Breeding Strategies. Crop Sciences, 45, 2405-2413. https://doi.org/10.2135/cropsci2004.0606

\section{Copyrights}

Copyright for this article is retained by the author(s), with first publication rights granted to the journal.

This is an open-access article distributed under the terms and conditions of the Creative Commons Attribution license (http://creativecommons.org/licenses/by/4.0/). 